van Heyningen, W. E. (1959). J. gen. Microbiol. 20, 291-300

\title{
The Fixation of Tetanus Toxin by Nervous Tissue
}

\author{
By W. E. vaN HEYNINGEN \\ Sir William Dunn School of Pathology, University of Oxford
}

SUMMARY: The fixation of tetanus toxin by nervous tissue (Wassermann-Takaki phenomenon, 1898) has been re-investigated. Fixation is greatly dependent on the concentration of toxin and of receptor. Toxin is fixed in preference to toxoid, but its toxicity does not appear to be markedly diminished by fixation. A biological assay of the toxin receptor in nervous tissue and its components has been devised. The receptor activity is not due to a cerebroside, as thought by Landsteiner \& Botteri (1906), but to some substance (present mainly in grey matter) that tends to associate with it.

Tetanus toxin acts primarily on the central nervous system, although it appears also to have at least some peripheral action (see Wright, 1955). Its action on the central nervous system has been shown by Brooks, Curtis \& Eccles (1955) to consist in suppressing synaptic inhibition, possibly either by preventing the release of the transmitter substance from the presynaptic terminal of the interneurone, or its access to the subsynaptic membrane of the motor neurone. In order to determine the biochemical lesion underlying this intervention it is necessary to identify the substance at the inhibitory synapse upon which the toxin acts, to study the action of the toxin on this substance, and to determine the consequences which follow immediately upon this action. It seemed possible that a re-investigation of the well known Wassermann-Takaki phenomenon might be a fruitful way of approaching the problem. Wassermann \& Takaki (1898) showed that when an emulsion of brain tissue was mixed with a few lethal doses of toxin the toxicity was decreased, and the decrease of toxicity was greater when the mixture was filtered before injection. Evidently the toxin was fixed on nervous tissue. Brain tissue was more effective than spinal cord, and grey matter more than white. This phenomenon attracted much attention during the following decade, and many workers attempted to identify the material in nervous tissue responsible for the fixation. The most effective work was that of Landsteiner \& Botteri (1906; see also Takaki, 1908), who showed that the 'protagon' component of nervous tissue had the greatest toxin receptor activity. Protagon is the component which is extracted from nervous tissue with hot ethanol after previous exhaustive extraction, first with acetone, then with ether; it is a mixture of sphingolipids, particularly the cerebrosides and sphingomyelins. Landsteiner \& Botteri and Takaki believed that the cerebroside phrenosine had powerful receptor activity, but were puzzled by the fact that whereas grey matter showed much greater receptor activity than white matter, it had a much smaller phrenosine content. Interest in the phenomenon then died out, and during the next fifty years little work was done on it.

The phenomenon seemed to be worth further study, however, because of 
its specificity. Thus it had been shown by Coleman (1924) not to apply to botulinus and diphtheria toxins, by Fulthorpe (1956) not to apply to diphtheria, Clostridium oedematiens, $C$. welchii and staphylococcus toxins, and by Pons (1938) and Fulthorpe (1956) not to apply to tetanus toxoid. This suggested that there might be a significant relationship between tetanus toxin and some component of the grey matter of nervous tissue. Since the inhibitory synapses are present in the grey matter it is reasonable to search for the susceptible substance of tetanus toxin in this tissue. It was decided therefore to confirm that the fixation is specific for tetanus toxin, to determine whether it is due to a particular component of nervous tissue, and if so, what this substance is, and how the toxin reacts with it. The first step was the development of a quantitative assay for the toxin receptor activity of nervous tissue and its various components.

\section{METHODS}

Toxin. The tetanus toxin preparation, XW 1322, was kindly supplied by Miss Mollie Barr of the Wellcome Research Laboratories. It was a dried precipitate obtained by saturating a culture filtrate of Clostridium tetani with $\left(\mathrm{NH}_{4}\right)_{2} \mathrm{SO}_{4}$. The powder consisted of $13.5 \%$ protein (Lowry, Rosebrough, Farr \& Randall, 1951) mixed with salts containing much $\left(\mathrm{NH}_{4}\right)_{2} \mathrm{SO}_{4}$. It contained 430,000 LD 50 doses (mice), 15.7 L + doses and $18 \mathrm{Lf} \mathrm{doses} / \mathrm{mg}$. dry weight, or 3,185,000 LD 50, $116 \mathrm{~L}+$, and $133 \mathrm{Lf} / \mathrm{mg}$. protein, i.e. 27,350 LD 50/ $\mathrm{L}+$ and $1 \cdot 146 \mathrm{Lf} / \mathrm{L}+$. Comparison with the purified toxin of Pillemer, Wittler, Burrell \& Grossberg (1948, 6.6 × 10 $\mathrm{MLD} / \mathrm{mg}$. N; 3400-3600 Lf $/ \mathrm{mg}$. N; $15.7 \% \mathrm{~N}$ ) shows that the preparation XW 1322 was about $25 \%$ pure (leaving aside its salt content), and somewhat less toxoided. There was no advantage in using pure toxin for this work, even if it could be prepared or were available, because the pure toxin readily denatures and spontaneously toxoids (Pillemer et al. 1948); in any case the pharmacological action of the toxin is so distinctive that there was no pressing need to separate it from irrelevant materials. The preparation of antitoxin, containing 1850 units/ml., was also supplied by Miss Mollie Barr.

Assay of toxin. Toxin and antitoxin were dissolved in $0.067 \mathrm{M}-$ phosphate buffer $(\mathrm{pH} 7)$ containing $\mathbf{0 . 3} \%(\mathrm{w} / \mathrm{v})$ gelatin. In determinations of LD 50 dose and $L+$ dose (at $0 \cdot 1$ antitoxin unit level), a series of $0.5 \mathrm{ml}$. volumes containing 1.25-fold dilutions (20\% steps) of toxin (mixed with 0.1 unit of antitoxin in the case of $\mathbf{L}+$ determinations) was injected subcutaneously into the hind limbs of 16-20 g. mice. Four to eight mice were used for each dilution of toxin and generally seven concentrations were used, to cover a four-fold range. Values for LD 50 and $L+$ were calculated from the deaths recorded in 7 days.

Figure 1 shows the smooth dose-response curves drawn through the data derived from several hundred determinations each of LD50 and $\mathbf{L}+$. They show that $140 \%$ of an LD50 dose, or $120 \%$ of an $\mathrm{L}+$ dose, killed all the mice injected, and $60 \%$ of an LD 50, or $80 \%$ of an $\mathrm{L}+$, killed none. This meant that assays of toxin could be carried out with reasonable accuracy and with relatively few mice, especially in the presence of antitoxin. In assays of $L_{+}$ 
one v ery seldom finds a dose, even when doses are spaced only $20 \%$ apart, that kills only some of the mice. In most assays either all the mice injected with a given dose die, or all survive; consequently the value or accuracy of the assay is very little affected whether 2 or 8 mice are used per dose.

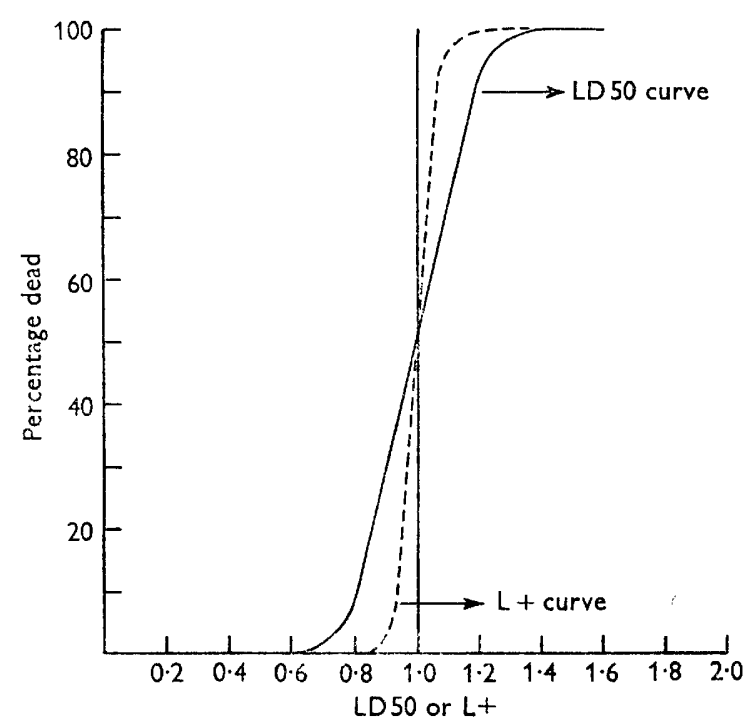

Fig. 1. Smooth dose-response curves drawn through data derived from several hundred determinations of LD50 and $\mathrm{L}+($ at $0 \cdot 1$ antitoxin unit level).

Determinations of $\mathbf{L f}$ were done at $50^{\circ}$, with the antitoxin concentration in successive tubes falling in $20 \%$ steps. The crude toxin preparation flocculated only in one zone, which was shown by an $\mathrm{L}+$ determination to be due to the toxin.

Fractionation of brain. Fresh or deep-frozen beef brain from the slaughterhouse was freed from blood and meninges under running tap water, minced in a Waring Blendor, and separated into fractions soluble in acetone, ether and hot $85 \%(\mathrm{v} / \mathrm{v})$ ethanol in water (protagon) by the method of Loening \& Thierfelder (1910). Fresh brain (1.6 kg.) yielded $110 \mathrm{~g}$. acetone-soluble material, $60 \mathrm{~g}$. ether-soluble material, and $28 \mathrm{~g}$. protagon. Protagon was also prepared from chicken brain in the same way. Crude phrenosine $(10 \mathrm{~g}$.) was prepared from the beef protagon by the method of Klenk \& Leupold (1944) and further purified $(6 \cdot 2 \mathrm{~g}$.) by the method of Carter \& Fujino (1956). Samples of pure phrenosine and sphingomyelin from brain were also kindly supplied by Dr H.E. Carter of Urbana and Professor E. Klenk of Cologne.

Protagon, phrenosine and sphingomyelin are insoluble in water, and when suspended in water, and the water brought to the boil and cooled, they form very stable opalescent suspensions showing myelin formation. They can be removed from these suspensions by centrifuging for $1 \mathrm{hr}$. at $5600 \mathrm{~g}(5000 \mathrm{rev}$.) min., $20 \mathrm{~cm}$. mean diam. angle centrifuge). 


\section{RESULTS \\ Adsorption from low concentrations of toxin}

For the assay of the receptor it was decided to apply the same principle as is used in the assay of antitoxin, that is, to determine the least amount of receptor (the Receptor Unit-RU) that would neutralize (in this case by removal by adsorption) a test dose of toxin. The test dose chosen at first was 10 LD 50, since the earlier workers had investigated the effect of brain emulsions on a few lethal doses of toxin. Estimations of the receptor content (RU-10 LD50/ mg.) of brain and its components were carried out as follows. To seven or

Table 1. Tetanus toxin receptor activity of brain and its components as measured in a low concentration of toxin (22 LD 50/ml.; $0.002 \mu$ g. toxic protein/ml.)

Receptor preparation RU-10LD50/mg. Receptor preparation RU-10LD50/mg.

Whole beef brain (dry weight)

Acetone-soluble fraction

Ether-soluble fraction

Whole brain protagon

$\begin{array}{rlr}\mathbf{1} \cdot 7 & \text { Extracted brain residue } & <\mathbf{0 . 7} \\ <\mathbf{0 . 7} & \text { Crude phrenosine } & \mathbf{1 . 8} \\ <\mathbf{0 . 7} & \text { Sphingomyelin } & <\mathbf{0 . 7}\end{array}$

$1 \cdot 8$

$0 \cdot 7$

eight $4 \mathrm{ml}$. volumes of a series of $\mathbf{1} \cdot \mathbf{4 3}$-fold dilutions ( $30 \%$ steps) in water of suspensions of brain, protagon, crude phrenosine and purified sphingomyelin were added equal volumes of toxin solution in gelatin phosphate buffer (pH 7) containing $44 \mathrm{LD} \mathrm{50} / \mathrm{ml}$. After mixing and standing for $2 \mathrm{hr}$. at $37^{\circ}$ the mixtures were centrifuged for $1 \mathrm{hr}$. at $5600 \mathrm{~g}$ and $0.5 \mathrm{ml}$. volumes of the supernatant fluids injected subcutaneously into mice, four mice being used for each mixture. From the deaths observed in 7 days the amount of receptor which adsorbed all but one of 11 LD 50 doses could be calculated. The values thus obtained are recorded in Table 1. This table confirms Landsteiner \& Botteri's (1906) observation that the toxin receptor activity of brain lies in its protagon component, and that the crude phrenosine component of protagon is active; and it shows that sphingomyelin, which has many of the physical properties of phrenosine (e.g. myelin formation in water), is inactive. The protagon component, however, had no more receptor activity than the brain from which it was derived, and since it comprises only about $8-10 \%$ of the dry weight of brain its receptor activity might be expected to be about 10 times as great. It was realized then that with a test dose of $10 \mathrm{LD} 50$ the concentration of toxin used, in terms of weight of toxic protein/unit volume, was extremely low, of the order of $0.002 \mu \mathrm{g} . / \mathrm{ml}$. Fulthorpe (1956) showed that the fixation of tetanus toxin by brain follows the usual laws of adsorption, i.e. the greater the concentration of toxin the greater the amount adsorbed. His experiments were carried out at toxin concentrations varying from 5 to $20 \mathrm{~L}+1$ ml., i.e. up to 50,000 times as great as those in the present experiments. It was decided therefore to use comparable concentrations of toxin.

\section{Adsorption from high concentrations of toxin}

Flocculation studies. At concentrations about $20 \mathrm{~L}+$ or $\mathbf{L f} / \mathbf{m l}$. toxin flocculates rapidly with equivalent concentrations of antitoxin, and it was 
hoped therefore to estimate receptor activity rapidly and in vitro by measuring the $\mathrm{Lf}$ content of a toxin solution before and after treatment with a receptor preparation. However, Table 2 shows that when this was done there was a sharp decrease in the $\mathrm{L}+$ content but no decrease in the apparent $\mathrm{Lf}$ content, although there was an increase in flocculating time (Kf). This observation is reminiscent of that of Fulthorpe (1956), who found that on two successive

\section{Table 2. Apparent failure of protagon to remove flocculating antigen while removing toxin}

\begin{tabular}{cccc} 
& \multicolumn{3}{c}{$\begin{array}{c}\text { Assays after treatment of toxin } \\
\text { preparation with protagon }\end{array}$} \\
\cline { 2 - 4 } mg. protagon/ml. & $\mathbf{L}+/ \mathrm{ml}$. & Apparent Lf/ml. & $\mathbf{K f}$ \\
0 & 52 & 60 & 480 \\
$0 \cdot 25$ & 42 & 55 & 923 \\
1 & 12 & 44 & 806 \\
$3 \cdot 8$ & 2 & 60 & 1888 \\
$7 \cdot 5$ & 0 & 60 & 1120 \\
15 & 0 & 60 & 1152 \\
Kf $=$ units antitoxin/ml. $\times$ flocculation time (min.).
\end{tabular}

adsorptions of toxin with dried horse brain there was a parallel decrease in $\mathbf{L}+$ and Lf contents, but on the third adsorption, when the $\mathbf{L}+$ content diminished to $70 \%$, the apparent Lf content doubled. There seems to be no explanation for these anomalous results, except possibly that the toxin preparation contained two antigens, one toxic and the other irrelevant, flocculating in the same zone at different times. In any case, as will be seen in the next section, there is no doubt that the toxin is adsorbed on the receptor.

Toxicity of toxin-receptor complex. Table 3 shows that when a suspension of receptor with toxin adsorbed on it was injected into mice the action of the adsorbed toxin was unimpaired and could be accounted for quantitatively.

Table 3. Quantitative recovery of toxin adsorbed on protagon

\section{$10 \mathrm{ml}$. Toxin-protagon mixture containing $100 \mathrm{~L}+$ toxin and $10 \mathrm{mg}$.} protagon, stood for $2 \mathrm{hr}$. at $37^{\circ}$ and centrifuged

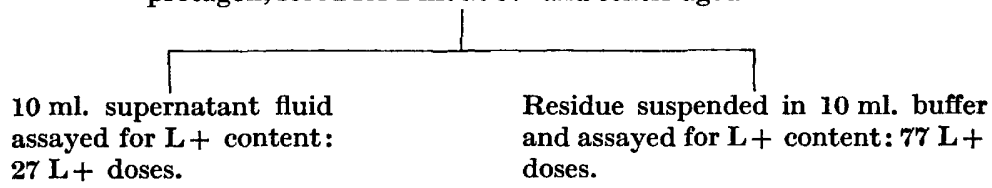

At low concentrations the action of toxin was somewhat diminished when injected together with receptor. Thus, while $1 \mathrm{mg}$. of a protagon preparation sufficed to protect mice against $10 \mathrm{LD} 50$ of toxin when it was centrifuged out before injection, $4 \mathrm{mg}$. of protagon were needed when injected together with the toxin. The toxicity of the toxin-protagon complex may be due to dissociation on dilution in the body fluids of the mice, since the lower the toxin concentration the less is adsorbed. This suggestion was supported by the finding that when protagon and toxin at a concentration of $30 \mathrm{~L}+/ \mathrm{ml}$. were 
stood for $2 \mathrm{hr}$., $0.64 \mathrm{mg}$. protagon were required to fix $20 \mathrm{~L}+$ units of toxin (see section below on assay of receptor), but when the same mixtures, after standing at $30 \mathrm{~L}+/ \mathrm{ml}$. for $2 \mathrm{hr}$., were diluted $1 / 40$, an equivalent of $8.5 \mathrm{mg}$. protagon were required to adsorb $20 \mathrm{~L}+$ doses.

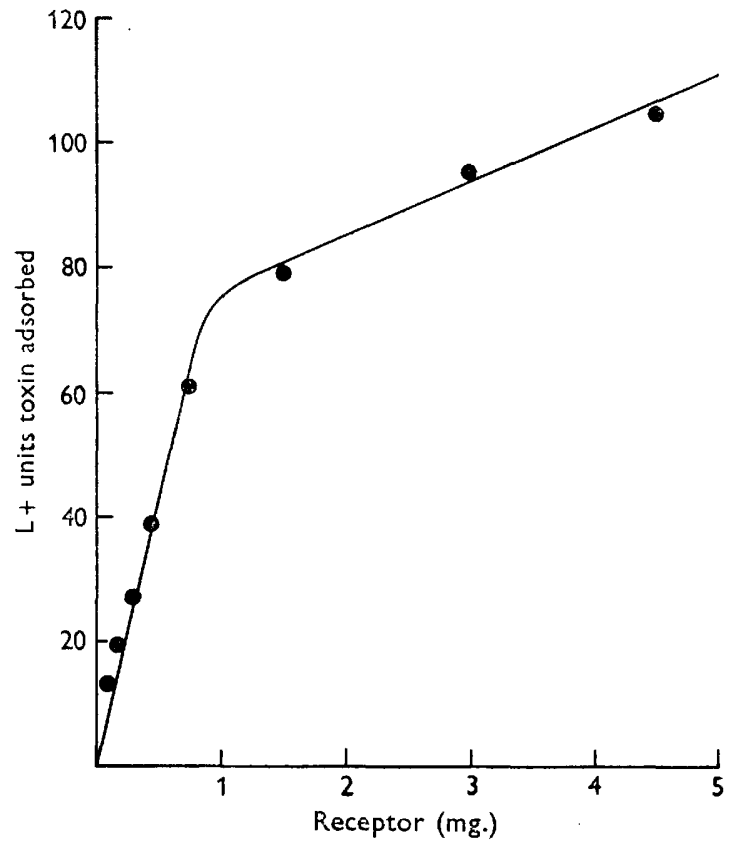

Fig. 2. Effect of increasing concentration of receptor on adsorption of toxin.

Effect of $p H$ value, temperature and salt concentration on adsorption of toxin. Experiments showed that adsorption of toxin by protagon decreased rapidly at values of $\mathrm{pH}$ above 7 . It was not possible to test adsorption at values of $\mathrm{pH}$ below 7 because the toxin precipitated. Adsorption was the same at $10^{\circ}$ as at $37^{\circ}$, and was somewhat inhibited in high concentrations of salt (in $8 \% \mathrm{NaCl}$ adsorption was $63 \%$ of that in $0.25 \% \mathrm{NaCl}$.).

Effect of receptor concentration on adsorption of toxin. Figure 2 shows the adsorption of toxin at constant concentration $(30 \mathrm{~L}+/ \mathrm{ml}$.) by increasing concentrations of protagon (0.0125-0.75 mg. $/ \mathrm{ml}$.). Adsorption was measured by difference between the $\mathrm{L}+$ values of the solutions before and after treatment with protagon in the usual way. The adsorption curve shows a narked change in slope for which no explanation is forthcoming. Table 4 shows that protagon selectively adsorbed toxin rather than toxoid, since the LD 50/L+

Table 4. Decrease in $L D 50 / L+$ ratio of toxin solution after treatment with $\mathbf{0 . 3} \mathrm{mg}$. protagon $/ \mathrm{ml}$. (selective adsorption of toxin)

Toxin before adsorption $\mathbf{L}+/ \mathbf{m l}$.

LD 50/ml.

LD 50/L +

Residual toxin after adsorption

30 $6 \cdot 85$
820,500

43,500
27,350 
ratio of residual material after adsorption was much smaller than that of the preparation before adsorption.

Assay of receptor. In applying the information displayed in Fig. 2 to the assay of the receptor it was clearly advisable to work on the steeper part of the curve, i.e. to determine the amount of receptor required to adsorb a proportion (not more than two-thirds) of a given amount of toxin, rather than the total. It was decided, therefore, to work at a toxin concentration of $30 \mathrm{~L}+/ \mathrm{ml}$., and to determine the concentration of receptor (RU-20 L $+/ \mathrm{ml}$.) that would fix $20 \mathrm{~L}+/ \mathrm{ml}$., i.e. two-thirds of the total concentration of toxin. This proportion should lie near the top of the steeper part of the curve. The assays were done as follows. Seven or eight $0.5 \mathrm{ml}$. volumes of a series of $\mathbf{1 . 4 3}$-fold dilutions (30\% steps) in water of suspensions of brain and its various components were mixed with equal volumes of toxin solution in gelatin phosphate buffer ( $\mathrm{pH} \mathrm{7)} \mathrm{containing} 60 \mathrm{~L}+/ \mathrm{ml}$. After standing for $2 \mathrm{hr}$. at room temperature the mixtures were centrifuged for $1 \mathrm{hr}$. at $5600 \mathrm{~g}$, and $0.5 \mathrm{ml}$. of each supernatant fluid (containing the unadsorbed residue of $15 \mathrm{~L}+$ ) mixed with $2 \mathrm{ml}$. of solution of antitoxin in gelatin phosphate buffer $(\mathrm{pH} 7)$ containing 2.5 units/ ml. (i.e. 5 units antitoxin). Samples $(0.5 \mathrm{ml}$.) from each mixture were then injected into two mice. Thus in effect the receptor was assayed against 30-10 L +, and the unadsorbed toxin was assayed by $\mathbf{L}+$ assay at the one unit level, which is more accurate than a direct assay of toxicity (e.g. see Fig. 1). It was found that two mice were quite sufficient for each dilution of receptor (i.e. 14 mice for 7 dilutions covering an eightfold range) since the same answers were invariably obtained when more than two mice were used. Moreover, the mice were not observed for more than 3 days, because those which received toxin received such enormous doses that they always died in 3 days. Deaths after 3 days were always adventitious.

The significance of the change of slope in Fig. 2, and the advantage of a test dose that is two-thirds of a given amount of toxin, is shown by the observation that although the weight of the Receptor Unit of a certain preparation of protagon was $0.58 \mathrm{mg}$. when measured against $30 \mathrm{~L}+$ doses of toxin +10 units antitoxin, it was $6.0 \mathrm{mg}$. when measured against $20 \mathrm{~L}+$ alone.

Table 5. Effect of concentration of toxin on receptor activity of protagon

$\begin{array}{cc}\text { Conc. toxin } & \text { RU-20 } \mathrm{L}+\text { / } \\ (\mathrm{L}+/ \mathrm{ml} .) & \text { mg. protagon } \\ 30 & 1 \cdot 6 \\ 60 & 4 \cdot 3 \\ 120 & 10 \cdot 0\end{array}$

Table 5 shows that the weight of the Receptor Unit decreased with increasing toxin concentration, as might be expected from Fulthorpe's (1956) observation that the higher the toxin concentration the greater the amount of toxin adsorbed. However, the greater consumption of toxin and antitoxin did not justify carrying out the assay at concentrations of toxin above $30 \mathrm{~L}+/ \mathrm{ml}$. 
Table 6 shows that this method of assay gave satisfactorily reproducible results. Table 7 shows the results of assays on various components of brain. The early observation that grey matter has more receptor activity than white

Table 6. Reproducibility of biological assays of receptor activity of a particular preparation of protagon determined on a number of occasions

$\begin{array}{cccc}\begin{array}{c}\text { Time after } \\ \text { first assay }\end{array} & \begin{array}{c}\text { RU-20 L + } \\ \text { (days) }\end{array} & \begin{array}{c}\text { Time after } \\ \text { first assay } \\ \text { (days) }\end{array} & \begin{array}{c}\text { RU-20 L + / } \\ \text { mg. protagon }\end{array} \\ \text { 0 } & \mathbf{2 \cdot 2} & \mathbf{2 3} & \mathbf{2 \cdot 0} \\ 0 & \mathbf{2 \cdot 2} & \mathbf{4 2} & \mathbf{1 \cdot 8} \\ \mathbf{7} & \mathbf{2 \cdot 0} & \mathbf{6 3} & \mathbf{2 \cdot 2} \\ \mathbf{9} & \mathbf{2 \cdot 2} & \mathbf{7 4} & \mathbf{2 \cdot 0} \\ \mathbf{2 1} & \mathbf{1 \cdot 7} & & \end{array}$

Table 7. Tetanus toxin-fixing capacity $(R U-20 L+/ m g$. $)$ of brain and its various components

\begin{tabular}{|c|c|c|c|}
\hline Receptor material & RU-20 L + /mg. & Receptor material & RU-20 L + /mg. \\
\hline Whole beef brain (dry wt.) & $0 \cdot 05$ & White matter protagon & $0 \cdot 3$ \\
\hline Grey matter & $0 \cdot 12$ & Spinal cord protagon & $<0.25$ \\
\hline White matter & 0.017 & Crude phrenosine & $1 \cdot 7$ \\
\hline Acetone-soluble fraction & $<0.03$ & Purified phrenosine & $<0.2$ \\
\hline Ether-soluble fraction & $<0 \cdot 03$ & Purified mixed cerebrosides & $<0.2$ \\
\hline Extracted residue & 0.03 & Sphingomyelin & $<0.03$ \\
\hline Whole brain protagon & $2 \cdot 2$ & Whole chicken brain (dry wt.) & $0 \cdot 10$ \\
\hline Grey matter protagon & $\mathbf{3} \cdot \mathbf{3}$ & Chicken brain protagon & $2 \cdot 0$ \\
\hline
\end{tabular}

is confirmed, and protagon from grey matter is shown to be more active than protagon from white matter or spinal cord. The data on chicken brain and the protagon derived from it are included because the chicken is extremely resistant to tetanus toxin. Metchnikoff (1898) claimed that chicken brain did not fix the toxin; evidently this claim cannot be confirmed. Comparison with Table 1 shows that when receptor activity was assayed against 500,000 LD 50 rather than $10 \mathrm{LD} 50$ (or $40 \mu \mathrm{g}$. toxic protein rather than $0 \cdot 001 \mu \mathrm{g}$.) a big difference was observed in the relative receptor activities of protagon and brain. Protagon and crude phrenosine were now about 40 times as active as brain. When phrenosine was further purified, however, it lost its receptor activity. Other cerebrosides, and sphingomyelin, also did not have appreciable activity.

\section{Destruction of toxin by psychosine sulphate}

Removal of the fatty acid from cerebrosides by alkaline hydrolysis gives rise to sphingosylgalactose (psychosine) from which a water-soluble sulphate can be prepared. Drury et al. (1936) showed that psychosine sulphate inactivated tetanus toxin but not other toxins. This observation has been confirmed in so far as a solution containing $150 \mu \mathrm{g}$. psychosine and $20 \mathrm{LD} 50 \mathrm{toxin} / \mathrm{ml}$. was found to be non-toxic. This inactivation is irreversible, however, and is probably due to denaturation of the toxin since psychosine sulphate is highly 
surface-active; a solution of it froths vigorously. It is unlikely that there is any connexion between the adsorption of toxin by protagon and its inactivation by psychosine sulphate.

\section{DISCUSSION}

The assays at both low (against $10 \mathrm{LD} 50$ doses) and high (against $20 \mathrm{~L}+$ doses) concentrations of tetanus toxin yielded qualitatively similar results, showing that the receptor activity of nervous tissue is in the protagon fraction and in no other fraction. However, we must consider the anomalous finding that at low toxin concentrations the receptor activity of the protagon fraction was not greater than that of whole brain, whereas at high toxin concentrations it was much greater. A possible explanation of this may lie in the well-known curvature of the adsorption isotherms of heterogeneous systems at low concentrations of adsorbate. At the excessively low concentration of toxin $\left(2 \cdot 6 \times 10^{-11} \mathrm{M}\right)$ used in the assay against $10 \mathrm{LD} 50$ doses slight differences in the curvature for brain and protagon might account for the anomaly.

The biological method for the assay of the tetanus toxin receptor, in comparison with many biological assays, is reasonably reproducible, accurate and quick, especially since a good idea of the final answer can be obtained on the day after injection. It might be advisable in the future to assay against $10 \mathrm{~L}+$ units of toxin $(30 \mathrm{~L}+$ doses of toxin +20 units of antitoxin) rather than $20 \mathrm{~L}+$ units ( $30 \mathrm{~L}+$ doses of toxin +10 units antitoxin) since the point for two-thirds adsorption of toxin lies perhaps too near the top end of the steep part of the curve in Fig. 2.

The demonstration that crude phrenosine has much receptor activity and purified phrenosine practically none, solves the problem which faced Landsteiner \& Botteri (1906) who believed that phrenosine was the receptor, but could not reconcile this with the fact that the phrenosine contents of grey and white matter were inversely proportional to their capacity to fix toxin. Evidently the receptor is a substance, mainly present in grey matter, which tends to associate with cerebrosides but is distinct from them. All attempts to separate such a substance from protagon by solvent extraction, adsorption on columns, etc., were unsuccessful, and it was decided to investigate the potentialities of counter-current distribution between immiscible solvents. This technique would require many hundreds of assays of receptor activity, and although the biological assay had been useful up to this stage it was too inaccurate, too laborious, too slow and too expensive to use on such a large scale. It was essential to devise a more practicable assay that could be carried out in vitro. This was examined in the following paper (van Heyningen, 1959).

\section{REFERENCES}

Brooks, V. B., Curtis, D. R. \& Eccles, J. C. (1955). The mode of action of tetanus toxin. Nature, Lond. 175, 120.

Carter, H. E. \& Fujino, Y. (1956). Biochemistry of the sphingolipides. IX. Configuration of cerebrosides. J. biol. Chem. 221, 879 . 
Coleman, G. E. (1924). Action of leucocytes and of brain tissue on toxin of B. botulinus. J. infect. Dis. 34, 614.

Drury, A. N., Miles, J. A. R., Platt, A. E., Plaut, G. \& Weil, H. (1936). Observations relating to psychosine sulphate: Its action upon bacteria, toxins, serum and red blood cells. J. Path. Bact. 42, 363.

Fulthorpe, A. J. (1956). Adsorption of tetanus toxin by brain tissue. J. Hyg., Camb. 54, 315.

KLENK, E. \& Leupold, F. (1944). Über eine vereinfachte Methode zur Darstellung von phosphorfreien Cerebrosiden und über die als Spaltprodukte auftretenden Fettsäuren. 18. Mitteilung über Cerebroside. Z. physiol. Chem. 281, 208.

Landsteiner, K. \& BotTeri, A. (1906). Über Verbindungen von Tetanustoxin mit Lipoiden. IV. Zbl. Bakt. (Orig.), 42, 562.

Loening, H. \& Thierfelder, H. (1910). Uber das Cerebron. IV. Mitteilung. $Z$. physiol. Chem. 68, 464 .

Lowry, O. H., Rosebrough, N. J., Farr, A. L. \& Randall, R. J. (1951). Protein measurement with the Folin phenol reagent. J. biol. Chem. 193, 265.

Metchnikoff, E. (1898). Recherches sur l'influence de l'organisme sur les toxines. Ann. Inst. Pasteur, 12, 81.

Pilfemer, L., Wittler, R. G., Burrell, J. I. \& Grossberg, D. B. (1948). The immunochemistry of toxins and toxoids. VI. Crystallization and characterization of tetanal toxin. J. exp. Med. 88, 205.

Pons, R. (1938). L'anatoxine tétanique est-elle une toxine ayant perdu son pouvoir de fixation sur le système nerveux? C. R. Soc. Biol., Paris, 129, 209.

Takakr, T. (1908). Über Tetanusgift bindende Bestandteile des Gehirns. Beitr. chem. Physiol. Path. 11, 288.

van Hexningen, W. E. (1959). Chemical assay of the tetanus toxin receptor in nervous tissue. J. gen. Microbiol. 20, 301.

WassermanN, A. \& TAKAKI, T. (1898). Über tetanusantitoxische Eigenschaften des normalen Centralnervensystems. Berl. klin. Wschr. 35, 5.

Wright, G. P. (1955). The neurotoxins of Clostridium botulinum and Clostridium tetani. Pharmacol. Rev. 7, 413. 